\title{
Effects of cyclohexanone analogues of curcumin on growth, apoptosis and NF-kB activity in PC-3 human prostate cancer cells
}

\author{
XINGCHUAN WEI ${ }^{1,2}$, ZHI-YUN DU $^{2,3}$, XIAO-XING CUI $^{4}$, MICHAEL VERANO $^{4}$, RONG QING MO ${ }^{2,3}$, \\ ZHI KAI TANG ${ }^{2,3}$, ALLAN H. CONNEY ${ }^{3,4}$, XI ZHENG $^{3,4}$ and $\mathrm{KUN} \mathrm{ZHANG}^{2,3}$ \\ ${ }^{1}$ Department of Chemistry and Chemical Engineering, Guangzhou University; \\ ${ }^{2}$ Laboratory of Natural Medicinal Chemistry and Green Chemistry, College of Light Industry and Chemical Engineering, \\ Guangdong University of Technology; ${ }^{3}$ Allan H. Conney Laboratory for Anticancer Research, \\ Guangdong University of Technology, Guangzhou 510006, P.R. China; \\ ${ }^{4}$ Susan Lehman Cullman Laboratory for Cancer Research, Department of Chemical Biology, \\ Ernest Mario School of Pharmacy, Rutgers, The State University of New Jersey, Piscataway, NJ 08854, USA
}

Received January 9, 2012; Accepted April 2, 2012

DOI: $10.3892 / \mathrm{ol} .2012 .710$

\begin{abstract}
Curcumin is a non-nutritive yellow pigment found in the spice turmeric, which is derived from the rhizome of the plant Curcuma longa Linn. Six cyclohexanone analogues of curcumin $\left(\mathrm{A}_{1}-\mathrm{A}_{6}\right)$ were investigated for their effects on growth and apoptosis in PC-3 human prostate cancer cells. The ability of these compounds to inhibit NF- $\mathrm{BB}$ activity in PC-3 cells was also determined. Five out of the six curcumin analogues $\left(\mathrm{A}_{2}-\mathrm{A}_{6}\right)$ had stronger inhibitory effects compared to curcumin on the growth of cultured PC-3 cells. Compounds $\mathrm{A}_{2}-\mathrm{A}_{6}$ also had stronger stimulatory effects on apoptosis in PC-3 cells than curcumin, and these curcumin analogues more potently inhibited NF- $\kappa$ B activity than curcumin. The inhibitory effects of these compounds on $\mathrm{NF}-\kappa \mathrm{B}$ activity correlated with their effects on growth inhibition and apoptosis stimulation in $\mathrm{PC}-3$ cells. The results of the present study provide a rationale for in vivo studies with $\mathrm{A}_{2}-\mathrm{A}_{6}$ using suitable animal models of prostate cancer.
\end{abstract}

Correspondence to: Dr Kun Zhang, Laboratory of Natural Medicinal Chemistry and Green Chemistry, College of Light Industry and Chemical Engineering, Guangdong University of Technology, 100 Waihuanxi Road, Higher Education Mega Center, Guangzhou 510006, P.R. China

E-mail: kzhang@gdut.edu.cn

Dr Xi Zheng, Susan Lehman Cullman Laboratory for Cancer Research, Department of Chemical Biology, Ernest Mario School of Pharmacy, Rutgers, The State University of New Jersey, 164 Frelinghuysen Road, Piscataway, NJ 08854, USA

E-mail: xizheng@rci.rutgers.edu

Key words: curcumin, analogues, cyclohexanone, prostate cancer, apoptosis

\section{Introduction}

Curcumin is a non-nutritive yellow pigment found in the spice turmeric, which is derived from the rhizome of the plant Curcuma longa Linn. Curcumin lacks toxicity in humans (1), and extensive research over several decades has revealed that curcumin possesses anticancer, anti-inflammatory, antioxidant, antiviral and anti-bacterial activities $(2,3)$. Curcumin suppressed cell proliferation or induced apoptosis in cultured prostate cancer cells and other types of cancer cells (4-10). Curcumin also inhibited prostate carcinogenesis (11). Studies from our laboratory and those of other authors have demonstrated enhanced anticancer activities of curcumin when combined with other anticancer agents (12-14). Findings of earlier studies showed that curcumin exerts a wide range of anticancer effects by modulating a diversity of signaling pathways, including nuclear factor- $\kappa \mathrm{B}$ $(\mathrm{NF}-\kappa \mathrm{B})$ and other pathways (15-20). Curcumin has entered clinical trials for certain types of human cancer (21-23). However, the clinical efficacy of curcumin is limited, which is likely to be due to its low bioavailability (21-23). It was suggested that the $\beta$-diketone moiety of curcumin causes instability and poor metabolic properties (24-26). Enhanced stability was found in curcumin analogues by deleting the $\beta$-diketone moiety of the molecule (27). Recently, it was demonstrated that the cyclohexanone analogues of curcumin have enhanced stability in biological medium compared to curcumin (28). The cyclohexanone-containing curcumin analogue 2,6-bisp[(3-methoxy-4-hydroxyphenyl)methylene)]cyclohexanone was found to be more potent than curcumin for inhibiting NF- $\mathrm{\kappa B}$ in human breast cancer cells in vitro (29).

In an earlier study, we synthesized a series of cyclohexanone curcumin analogues and determined their inhibitory effect on the activity of aldose reductase (30). In the present study, we investigated the effects of these curcumin analogues on the growth and apoptosis of human prostate cancer PC-3 cells. We also determined the inhibitory effect of these analogues on the activation of NF- $\mathrm{B}$ in PC-3 cells using the 
luciferase reporter assay. Results of our study demonstrated that compounds $\mathrm{A}_{2}-\mathrm{A}_{6}$ have stronger effects for inhibiting growth and stimulating apoptosis in PC-3 cells compared to curcumin. We also found that these curcumin analogues have stronger effects than curcumin for inhibiting NF- $\kappa \mathrm{B}$ activity in $\mathrm{PC}-3$ cells.

\section{Materials and methods}

Chemistry. A series of cyclohexanone curcumin analogues were synthesized by coupling the appropriate substituted benzaldehyde with cyclohexanone as previously described (30). Characterization of the compounds, 2,6-bis(4-hydroxybenzylidene)-cyclohexanone $\left(A_{1}\right)$, 2,6-bis(3,4-dihydroxybenzylidene)-cyclohexanone $\left(\mathrm{A}_{2}\right)$, 2,6-bis(4-hydroxy-3-methoxybenzylidene)-cyclohexanone $\left(\mathrm{A}_{3}\right)$, 2,6-bis(3,5-di-tert-butyl-4-hydroxylbenzylidene)-cyclohexanone $\left(\mathrm{A}_{4}\right), 2,6$-bis(3,4-dimethoxybenzylidene)-cyclohexanone $\left(\mathrm{A}_{5}\right)$ and 2,6-bis(4-hydroxy-3,5-dimethoxybenzylidene)-cyclohexanone $\left(\mathrm{A}_{6}\right)$, was previously described in detail (30).

Cell culture and reagents. PC-3 cells were obtained from the American Type Culture Collection (ATCC; Rockville, MD, USA). Curcumin was obtained from Sigma-Aldrich (St. Louis, MO, USA). The RPMI-1640 tissue culture medium, penicillin-streptomycin, L-glutamine and fetal bovine serum (FBS) were obtained from Gibco (Grand Island, NY, USA). The PC-3 cells were maintained in RPMI-1640 culture medium containing $10 \%$ FBS supplemented with penicillin (100 U/ml)-streptomycin $(100 \mu \mathrm{g} / \mathrm{ml})$ and L-glutamine ( $300 \mu \mathrm{g} / \mathrm{ml})$. Cultured cells were grown in a humidified atmosphere of $5 \% \mathrm{CO}_{2}$ at $37^{\circ} \mathrm{C}$, and were passaged twice a week. Curcumin and its analogues were dissolved in DMSO and the final concentration of DMSO in all experiments was $0.1 \%$.

MTT assay. PC-3 cells were seeded at a density of $0.2 \times 10^{5}$ cells $/ \mathrm{ml}$ in medium in 96 -well plates $(0.2 \mathrm{ml} /$ well $)$ and incubated for $24 \mathrm{~h}$. The cells were then treated with various concentrations $(0.5-10 \mu \mathrm{M})$ of the different curcumin analogues for $72 \mathrm{~h}$. Following treatment, $200 \mu \mathrm{l}$ 3-[4,5-dimethylthiazol-2-yl]-2,5-diphenyl tetrazoliumbromide $(0.5 \mathrm{mg} / \mathrm{ml}$ in PBS) was added to each well of the plate and incubated for $2 \mathrm{~h}$. The plate was then centrifuged at $1,000 \mathrm{rpm}$ for $5 \mathrm{~min}$ at $4^{\circ} \mathrm{C}$. Following removal of the medium, $0.1 \mathrm{ml}$ DMSO was added to each well. The absorbance was recorded on a microplate reader at $540 \mathrm{~nm}$. The effect of different curcumin analogues on cell growth was assessed as the percentage cell growth compared to DMSO-treated cells.

Determination of the number of viable cells. The number of viable cells following each treatment was determined using the trypan blue exclusion assay (31). In brief, $80 \mu \mathrm{l}$ of cell suspension was mixed with $20 \mu \mathrm{l}$ of $0.4 \%$ trypan blue solution and incubated for $2 \mathrm{~min}$. The cells were then examined under a light microscope (Nikon Optiphot, Japan). Blue cells were counted as dead cells and cells that did not absorb dye were counted as live cells.

Assessment of apoptotic cells by morphology and activation of caspase-3. Apoptotic cells were determined by morphological assessment in cells stained with propidium iodide $(32,33)$. Cytospin slides were prepared following each experiment and cells were fixed with acetone/methanol (1:1) at room temperature for $10 \mathrm{~min}$, followed by $10 \mathrm{~min}$ of propidium iodide staining ( $1 \mu \mathrm{g} / \mathrm{ml}$ in PBS), and were then analyzed using a fluorescence microscope (Nikon Eclipse TE200, Japan). Apoptotic cells were identified by classical morphological features, including nuclear condensation, cell shrinkage and formation of apoptotic bodies $(32,33)$.

Caspase-3 activation was measured using an EnzoLyte AMC Caspase-3 Assay Fluorimetric kit (AnaSpec, Fremont, CA, USA) according to the manufacturer's instructions (34). A total of $1 \times 10^{5}$ cells were plated in triplicate in a flat-bottomed 96-well plate. Cells were treated with different curcumin analogues for $72 \mathrm{~h}$. Following treatment, caspase-3 substrate was added to each well. Plates were incubated at room temperature for $30 \mathrm{~min}$. Fluorescence intensity was measured in a Tecan Inifinite M200 plate reader (Tecan US Inc., Durham, NC, USA).

$N F-\kappa B$-dependent reporter gene expression assay. $\mathrm{NF}-\kappa \mathrm{B}$ transcriptional activity was measured using the $\mathrm{NF}-\kappa \mathrm{B}$-luciferase reporter gene expression assay (35). An $\mathrm{NF}-\kappa \mathrm{B}$ luciferase construct was stably transfected into PC-3 cells and a single stable clone, PC-3 C4 (35), was used. PC-3 $\mathrm{C} 4$ cells were treated with different curcumin analogues for $24 \mathrm{~h}$, and the NF- $\kappa \mathrm{B}$-luciferase activities were measured using luciferase assay kits from Promega (Madison, WI, USA). Following treatment, the cells were washed with ice-cold phosphate-buffered saline (PBS), and harvested in $1 \mathrm{X}$ reporter lysis buffer. Following centrifugation, $10 \mu \mathrm{l}$ aliquots of the supernatants were measured for luciferase activity using a Luminometer from Turner Designs Inc., (Sunnyvale, CA, USA). The luciferase activity was normalized against known protein concentrations, and expressed as the percentage of luciferase activity in the control cells, which were treated with DMSO solvent. The protein level was determined using a Bio-Rad protein assay kit (Bio-Rad, Hercules, CA, USA) according to the manufacturer's instructions.

Statistical analysis. The analysis of variance (ANOVA) with the Tukey-Kramer multiple comparison test was used for the comparison of growth inhibition as determined by the trypan blue assay and determination of the NF- $\mathrm{BB}$-luciferase activities in cultured PC-3 cells that were treated with different curcumin analogues.

\section{Results}

Inhibitory effect of curcumin and its analogues on the growth of $\mathrm{PC}-3$ cells. The inhibitory effects of curcumin and its analogues $\mathrm{A}_{1}-\mathrm{A}_{6}$ on the growth of cultured PC-3 cells were determined using the MTT assay. For each experiment, curcumin was evaluated as the positive control. The inhibitory effects of curcumin did not significantly vary between different experiments. Data from the curcumin incubations were averaged (Fig. 1). Curcumin and its analogues $A_{1}-A_{6}$ inhibited the growth of PC-3 cells in a concentration-dependent manner (Fig. 1). $\mathrm{A}_{4}$ was the strongest curcumin analogue for inhibiting the growth of PC-3 cells, as determined by the 
A

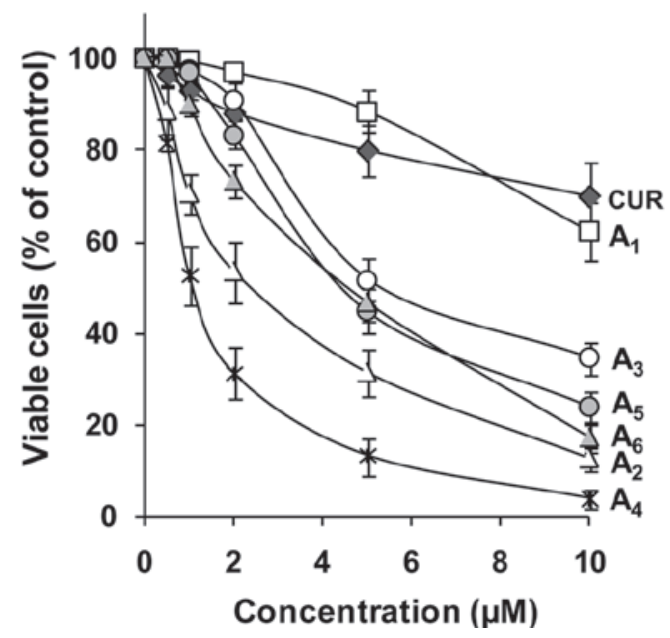

B

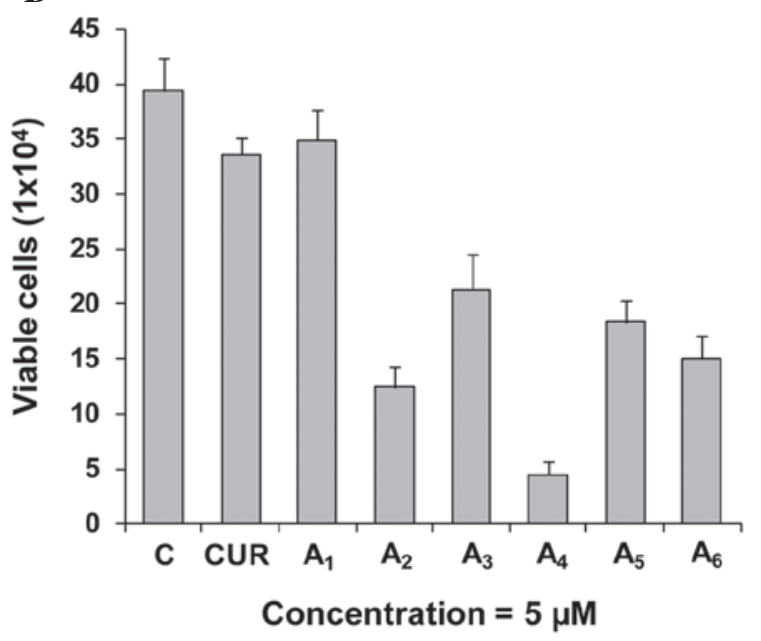

Figure 1. Effects of curcumin analogues on the growth of human prostate cancer PC-3 cells. PC-3 cells were seeded at a density of $0.2 \times 10^{5}$ cells $/ \mathrm{ml}$ of medium in 96 -well plates $(0.2 \mathrm{ml} /$ well $)$ and incubated for $24 \mathrm{~h}$. The cells were then treated with various concentrations $(0.5-10 \mu \mathrm{M})$ of the different compounds for $72 \mathrm{~h}$. (A) Effects of the different compounds on the growth of PC-3 cells were determined by the MTT assay and (B) the trypan blue exclusion assay. Each value is the mean $\pm \mathrm{SD}$ from three experiments. C, control; CUR, curcumin.
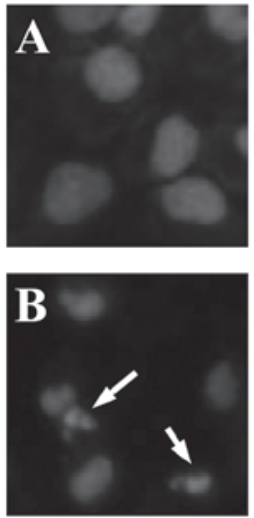

C

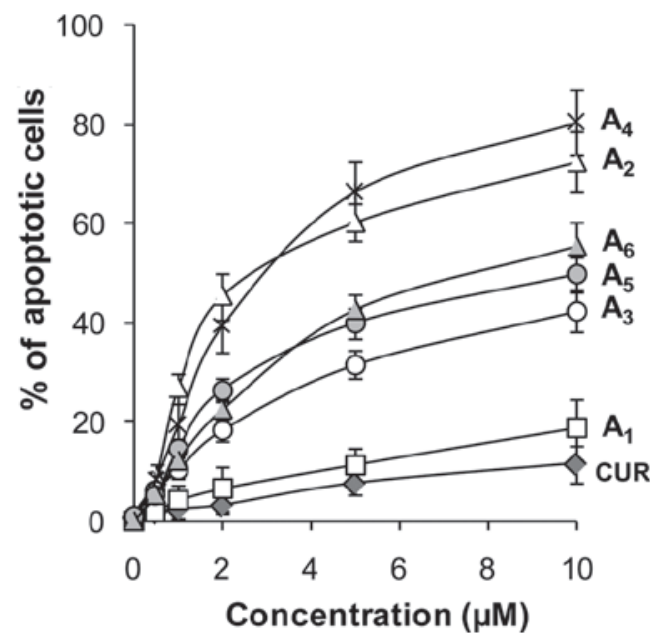

D

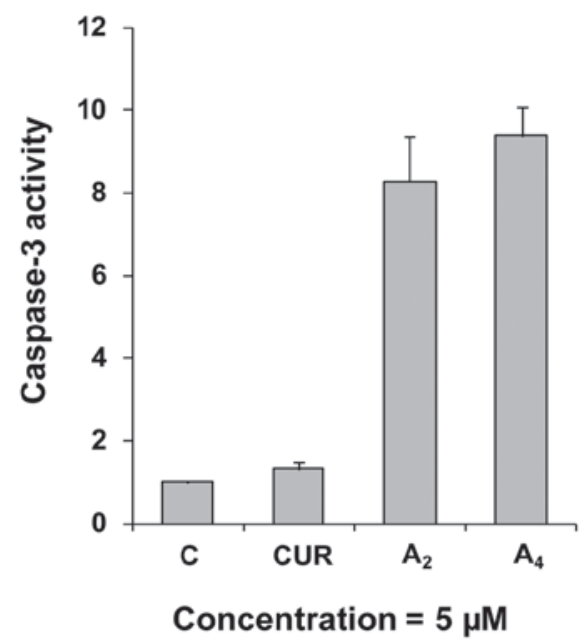

Figure 2. Effects of curcumin analogues on apoptosis. PC-3 cells were seeded at a density of $0.2 \times 10^{5}$ cells/ml of medium in 35 -mm tissue culture dishes $(2 \mathrm{ml} /$ dish) and incubated for $24 \mathrm{~h}$. The cells were then treated with various concentrations $(0.5-10 \mu \mathrm{M})$ of the different compounds for $72 \mathrm{~h}$. (A and B) Representative micrographs of propidium iodide-stained controls and $\mathrm{A}_{4}(5 \mu \mathrm{M})$-treated PC-3 cells. Arrows indicate apoptotic cells. (C) Percentage of apoptotic cells as determined by morphological assessment in PC-3 cells treated with the various compounds. (D) Caspase- 3 activities in PC-3 cells treated with curcumin, $\mathrm{A}_{2}$ and $\mathrm{A}_{4}$. Each value is the mean $\pm \mathrm{SD}$ from three experiments. $\mathrm{C}$, control; CUR, curcumin.

MTT assay, followed by $\mathrm{A}_{2}, \mathrm{~A}_{6}, \mathrm{~A}_{5}, \mathrm{~A}_{3}$ and $\mathrm{A}_{1}$ (Fig. 1A). In additional experiments, the effects of different curcumin analogues on cell growth were determined by the trypan blue exclusion assay. Compounds $\mathrm{A}_{2}-\mathrm{A}_{6}$ were more potent for decreasing the number of viable PC-3 cells as compared to curcumin (Fig. 1B). Statistical analysis using ANOVA with the Tukey-Kramer test demonstrated that the differences in the number of viable cells between the curcumin-treated group and any curcumin analogue-treated group (except the $\mathrm{A}_{1}$-treated group) were statistically significant $(\mathrm{P}<0.001)$. The number of viable cells was significantly lower in the $\mathrm{A}_{4}$-treated group than in the curcumin-treated or any other curcumin analogue-treated group $(\mathrm{P}<0.05$ compared to the $\mathrm{A}_{2}$-treated group; $\mathrm{P}<0.001$ compared to other curcumin analogue-treated groups).

Stimulatory effect of curcumin analogues on apoptosis in PC-3 cells. Effects of the curcumin analogues $\mathrm{A}_{1}-\mathrm{A}_{6}$ on apoptosis in PC-3 cells were determined by morphological assessment of apoptotic cells. Apoptotic cells were identified by classical morphological features, including nuclear condensation, cell shrinkage and formation of apoptotic bodies. Morphologically distinct apoptotic cells from representative samples are shown in Fig. 2B. Treatment of PC-3 cells with curcumin resulted 


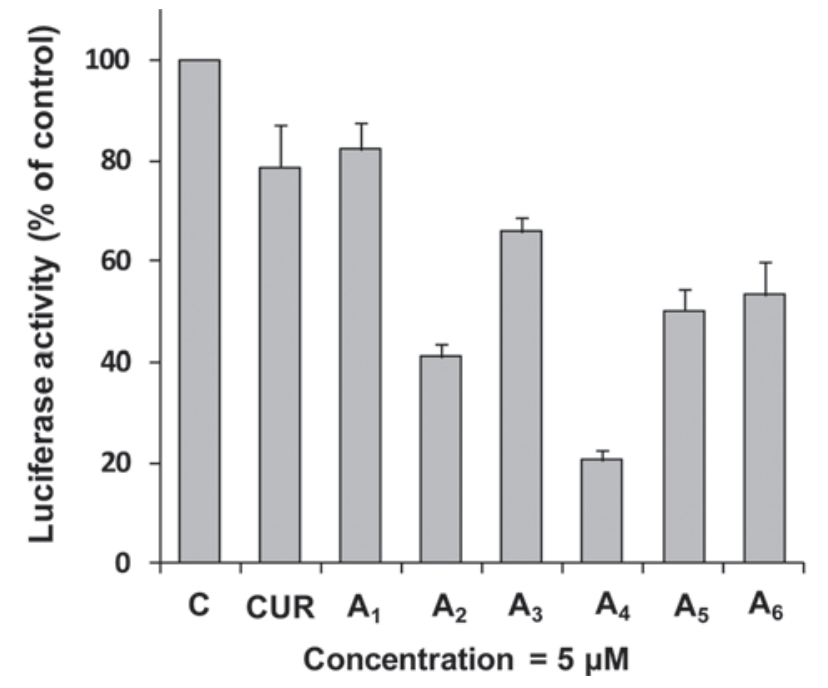

Figure 3. Effects of curcumin and its analogues $A_{1}-A_{6}$ on NF- $k B$ transcriptional activity in PC-3 cells. PC-3 C4 cells were seeded at a density of $0.2 \times 10^{5}$ cells $/ \mathrm{ml}$ of medium in $35-\mathrm{mm}$ culture dishes $(2 \mathrm{ml} / \mathrm{dish})$ and incubated for $24 \mathrm{~h}$. The cells were then treated with different compounds $(5 \mu \mathrm{M})$ for $24 \mathrm{~h}$. The NF- $\mathrm{BB}$ transcriptional activity was measured by a luciferase activity assay. Each value is the mean \pm SD from three experiments. C, control; CUR, curcumin.
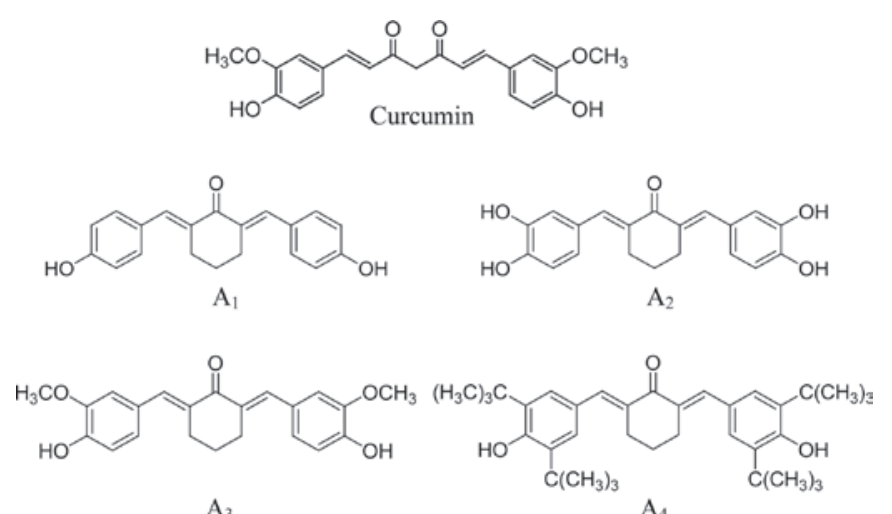

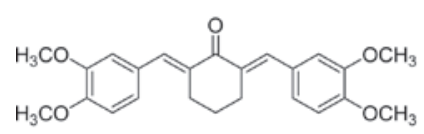

$\mathrm{A}_{5}$

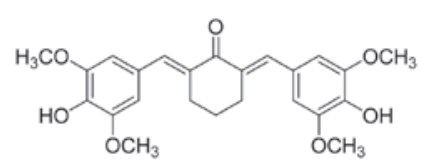

$\mathrm{A}_{6}$
Figure 4. Structures of curcumin and its analogues $A_{1}-A_{6}$.

in a small increase in apoptotic cells (Fig. 2C). Treatment with compounds $\mathrm{A}_{1}-\mathrm{A}_{6}$ stimulated apoptosis in PC-3 cells in a concentration-dependent manner (Fig. 2C). Compounds $\mathrm{A}_{2}$ and $\mathrm{A}_{4}$ demonstrated stronger stimulatory effects on apoptosis in PC-3 cells compared to the other compounds. The effect of the two strongest compounds $\mathrm{A}_{2}$ and $\mathrm{A}_{4}$ on activation of caspase- 3 in comparison to curcumin was determined. Treatment of PC-3 cells with curcumin caused only a small increase in caspase-3 activity, while treatment with $\mathrm{A}_{2}$ and $\mathrm{A}_{4}$ caused an 8.2- and 9.3-fold increase in caspase-3 activity, respectively (Fig. 2D). Our results identified $\mathrm{A}_{2}$ and $\mathrm{A}_{4}$ as the two curcumin analogues that had the greatest effect for stimulating apoptosis in PC-3 cells.
Effect of curcumin analogues on $N F-\kappa B$ activity. To investigate the effect of $\mathrm{A}_{1}-\mathrm{A}_{6}$ on activation of NF- $\mathrm{kB}$ activity, we used an NF- $\kappa B$-luciferase reporter gene expression assay in PC-3 C4 cells. PC-3 C4 is a cell line derived from the stable transfection of PC-3 cells with an NF- $\kappa B$ luciferase construct (35). In these experiments, $\mathrm{PC}-3 \mathrm{C} 4$ cells were treated with different concentrations of curcumin and its analogues $A_{1}-A_{6}$ for $24 \mathrm{~h}$. Treatment of PC-3 C4 cells with curcumin or $\mathrm{A}_{1}$ (both $5 \mu \mathrm{M}$ )

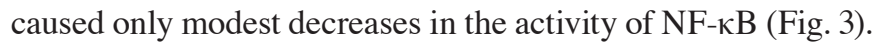
Treatment with $\mathrm{A}_{2}-\mathrm{A}_{6}$ (all at $5 \mu \mathrm{M}$ ) caused a further decrease in NF- $\kappa \mathrm{B}$ transcriptional activity. Statistical analysis using ANOVA with the Tukey-Kramer test demonstrated that NF- $\mathrm{KB}$ activity was significantly lower in the $\mathrm{A}_{4}$-treated group than in any other treated group $\left(\mathrm{P}<0.01\right.$ compared to the $\mathrm{A}_{2}$-treated group; $\mathrm{P}<0.001$ compared to other curcumin analogue-treated groups). There were good correlations between inhibition of NF- $\kappa B$ activity and cell growth inhibition $(r=0.97)$, and between inhibition of NF- $\mathrm{KB}$ activity and apoptosis stimulation $(\mathrm{r}=0.96)$ in the PC-3 cells treated with all compounds at $5 \mu \mathrm{M}$.

Analysis of structure-activity correlation. Six curcumin analogues $\left(\mathrm{A}_{1}-\mathrm{A}_{6}\right)$ that contain a five-carbon linker with a mono-carbonyl group (cyclohexanone linker) were evaluated for anticancer activities in human prostate cancer PC-3 cells. All of the curcumin analogues, with the exception of $A_{1}$, had stronger inhibitory effects on cell growth and stronger stimulatory effects on the apoptosis of PC-3 cells compared to curcumin. Although the structures of $\mathrm{A}_{3}$ and curcumin are the same, with the exception of their middle linker (Fig. 4), the anticancer activity of $\mathrm{A}_{3}$ was stronger than that of curcumin (Fig. 1) suggesting that a cyclohexanone linker increases anticancer activity. A comparison of the six curcumin analogues (all with the same mono-carbonyl linker) revealed that anticancer activity was significantly influenced by substituents on the benzene rings. The presence of a methoxy group on both sides of the $p$-phenol group markedly increased activity compared to a compound with a methoxy group on only one side $\left(A_{3}\right.$ vs. $\left.A_{6}\right)$. Tert-butyl substituents on both sides of the $p$-phenol group $\left(\mathrm{A}_{4}\right)$ had the strongest anticancer effect among all of the studied compounds. Comparison of $A_{1}$ and $A_{2}$ suggested that o-dihydroxyl substituents on both benzene rings $\left(\mathrm{A}_{2}\right)$ had stronger activity than an analogue with a single hydroxyl group on each side $\left(\mathrm{A}_{1}\right)$.

\section{Discussion}

In the present study, we demonstrated that a series of cyclohexanone curcumin analogues $\left(\mathrm{A}_{2}-\mathrm{A}_{6}\right)$ had stronger anticancer activities than curcumin in cultured human prostate cancer PC-3 cells. Among the curcumin analogues, $\mathrm{A}_{4}$ demonstrated a stronger inhibitory effect on the growth of PC-3 cells than any of the other curcumin analogues. Compounds $\mathrm{A}_{2}$ and $\mathrm{A}_{4}$ were stronger than the other compounds for stimulating apoptosis. In addition, we found that all curcumin analogues tested (except for $\mathrm{A}_{1}$ ) were more potent inhibitors of NF- $\mathrm{KB}$ in PC-3 cells than curcumin. $\mathrm{A}_{4}$ was the most potent compound among the six curcumin analogues tested for inhibiting the activation of NF-kB.

Extensive studies have shown that curcumin exerts a wide range of antitumor effects through modulation of significant 
signaling pathways, including transcription factor $\mathrm{NF}-\kappa \mathrm{B}$ and other pathways $(15-20,36)$. Of those involved in antitumor effects, $\mathrm{NF}-\kappa \mathrm{B}$ is generally regarded as an important target of curcumin $(16,37)$. NF- $\kappa \mathrm{B}$ has been linked to cell proliferation, invasion, angiogenesis, metastasis, suppression of apoptosis and chemoresistance in multiple tumors $(38,39)$. In addition, evidence suggests that $\mathrm{NF}-\kappa \mathrm{B}$ is significant in the growth and radio/chemoresistance of prostate cancer (40-44). Curcumin is able to suppress NF- $\kappa \mathrm{B}$ activation by an Akt-dependent or Akt-independent inhibition of IKK $(15,16,45)$. Certain curcumin analogues, including 3,5-bis(2-flurobenzylidene) piperidin-4-one (EF24) have been found to have a potent inhibitory effect on $\mathrm{NF}-\kappa \mathrm{B}(46)$. In the present study, we identified that 5 out of 6 cyclohexanone curcumin analogues tested had a more potent inhibitory effect than curcumin on activation of NF- $\kappa \mathrm{B}$ in PC-3 cells. The effects of these curcumin analogues on growth inhibition and apoptosis stimulation were associated with their inhibitory effect on activation of $N F-\kappa B$. This result indicates that inhibition of $\mathrm{NF}-\kappa \mathrm{B}$ activation may be involved in growth inhibition and apoptosis induction in PC-3 cells treated with these curcumin analogues.

Based on the analysis of the correlation between the structures of curcumin analogues and their effects on the growth and apoptosis of human prostate cancer PC-3 cells, analogues with a cyclohexanone linker between the two benzene rings enhance anticancer effects. Substituents on the benzene rings of the analogues also affect their activities. The analogue with a tert-butyl substituent on both sides of the $p$-phenol group $\left(\mathrm{A}_{4}\right)$ demonstrated stronger anticancer activity than the other analogues, suggesting that the introduction of more hydrophobic groups on both sides of the $p$-phenol group may be an important strategy for the development of more potent compounds with anti-prostate cancer activity.

\section{Acknowledgements}

This study was supported by the 2011 Guangdong Province Leadership Grant, and by departmental funds from the Department of Chemical Biology at the Ernest Mario School of Pharmacy at Rutgers University. The authors thank Ms. Annette Dionisio for her excellent help in the preparation of this manuscript.

\section{References}

1. Lao CD, Ruffin MT 4th, Normolle D, Heath DD, Murray SI, Bailey JM, Boggs ME, Crowell J, Rock CL and Brenner DE: Dose escalation of a curcuminoid formulation. BMC Complement Altern Med 6: 10, 2006.

2. Goel A, Kunnumakkara AB and Aggarwal BB: Curcumin as 'Curecumin': from kitchen to clinic. Biochem Pharmacol 75: 787-809, 2008.

3. Aggarwal BB and Sung B: Pharmacological basis for the role of curcumin in chronic diseases: an age-old spice with modern targets. Trends Pharmacol Sci 30: 85-94, 2009.

4. Moragoda L, Jaszewski R and Majumdar AP: Curcumin induced modulation of cell cycle and apoptosis in gastric and colon cancer cells. Anticancer Res 21: 873-878, 2001.

5. Anto RJ, Mukhopadhyay A, Denning K and Aggarwal BB: Curcumin (diferuloylmethane) induces apoptosis through activation of caspase-8, BID cleavage and cytochrome c release: its suppression by ectopic expression of Bcl-2 and Bcl-xl. Carcinogenesis 23: 143-150, 2002
6. Squires MS, Hudson EA, Howells L, Sale S, Houghton CE, Jones JL, Fox LH, Dickens M, Prigent SA and Manson MM: Relevance of mitogen activated protein kinase (MAPK) and phosphotidylinositol-3-kinase/protein kinase B (PI3K/PKB) pathways to induction of apoptosis by curcumin in breast cells. Biochem Pharmacol 65: 361-376, 2003.

7. Hanif R, Qiao L, Shiff SJ and Rigas B: Curcumin, a natural plant phenolic food additive, inhibits cell proliferation and induces cell cycle changes in colon adenocarcinoma cell lines by a prostaglandin-independent pathway. J Lab Clin Med 130: 576-584, 1997.

8. Mukhopadhyay A, Bueso-Ramos C, Chatterjee D, Pantazis P and Aggarwal BB: Curcumin downregulates cell survival mechanisms in human prostate cancer cell lines. Oncogene 20: 7597-7609, 2001.

9. Piantino CB, Salvadori FA, Ayres PP, Kato RB, Srougi V, Leite KR and Srougi M: An evaluation of the anti-neoplastic activity of curcumin in prostate cancer cell lines. Int Braz J Urol 35: 354-360, 2009.

10. Hilchie AL, Furlong SJ, Sutton K, Richardson A, Robichaud MR, Giacomantonio CA, Ridgway ND and Hoskin DW: Curcumin-induced apoptosis in PC3 prostate carcinoma cells is caspase-independent and involves cellular ceramide accumulation and damage to mitochondria. Nutr Cancer 62: 379-389, 2010.

11. Teiten MH, Gaascht F, Eifes S, Dicato M and Diederich $M$ : Chemopreventive potential of curcumin in prostate cancer. Genes Nutr 5: 61-74, 2010.

12. Cabrespine-Faugeras A, Bayet-Robert M, Bay JO, Chollet $P$ and Barthomeuf C: Possible benefits of curcumin regimen in combination with taxane chemotherapy for hormone-refractory prostate cancer treatment. Nutr Cancer: 62: 148-153, 2010.

13. Ide H, Tokiwa S, Sakamaki K, Nishio K, Isotani S, Muto S, Hama T, Masuda H and Horie S: Combined inhibitory effects of soy isoflavones and curcumin on the production of prostatespecific antigen. Prostate 70: 1127-1133, 2010.

14. Khor TO, Keum YS, Lin W, Kim JH, Hu R, Shen G, Xu C, Gopalakrishnan A, Reddy B, Zheng X, Conney AH and Kong AN: Combined inhibitory effects of curcumin and phenethyl isothiocyanate on the growth of human PC-3 prostate xenografts in immunodeficient mice. Cancer Res 66: 613-621, 2006.

15. Aggarwal BB and Shishodia S: Molecular targets of dietary agents for prevention and therapy of cancer. Biochem Pharmacol 71: 1397-1421, 2006

16. Lin YG, Kunnumakkara AB, Nair A, Merritt WM, Han LY, Armaiz-Pena GN, Kamat AA, Spannuth WA, Gershenson DM, Lutgendorf SK, Aggarwal BB and Sood AK: Curcumin inhibits tumor growth and angiogenesis in ovarian carcinoma by targeting the nuclear factor-kappaB pathway. Clin Cancer Res 13: 3423-3430, 2007.

17. Kunnumakkara AB, Guha S, Krishnan S, Diagaradjane P, Gelovani J and Aggarwal BB: Curcumin potentiates antitumor activity of gemcitabine in an orthotopic model of pancreatic cancer through suppression of proliferation, angiogenesis, and inhibition of nuclear factor-kappaB-regulated gene products. Cancer Res 67: 3853-3861, 2007.

18. Sun ZJ, Chen G, Zhang W, Hu X, Liu Y, Zhou Q, Zhu LX and Zhao YF: Curcumin dually inhibits both mammalian target of rapamycin and nuclear factor- $\mathrm{\kappa B}$ pathways through a crossed phosphatidylinositol 3-kinase/Akt/IkB kinase complex signaling axis in adenoid cystic carcinoma. Mol Pharmacol 79: 106-118, 2011.

19. Jutooru I, Chadalapaka G, Lei P and Safe S: Inhibition of NFkappaB and pancreatic cancer cell and tumor growth by curcumin is dependent on specificity protein down-regulation. J Biol Chem 285: 25332-25344, 2010.

20. Guo H, Yu JH, Chen K and Ye ZQ: Curcumin induced the expression of inhibitor kappaBalpha protein in human prostate cancer cells. Zhonghua Wai Ke Za Zhi 44: 1256-1259, 2006.

21. Anand P, Sundaram C, Jhurani S, Kunnumakkara AB and Aggarwal BB: Curcumin and cancer: an 'old-age' disease with an 'age-old' solution. Cancer Lett 267: 133-164, 2008.

22. Dhillon N, Aggarwal BB, Newman RA, Wolff RA, Kunnumakkara AB, Abbruzzese JL, Ng CS, Badmaev V and Kurzrock R: Phase II trial of curcumin in patients with advanced pancreatic cancer. Clin Cancer Res 14: 4491-4499, 2008.

23. Cheng AL, Hsu CH, Lin JK, Hsu MM, Ho YF, Shen TS, Ko JY, Lin JT, Lin BR, Ming-Shiang W, Yu HS, et al: Phase I clinical trial of curcumin, a chemopreventive agent, in patients with high-risk or pre-malignant lesions. Anticancer Res 21: 2895-2900, 2001. 
24. Wang YJ, Pan MH, Cheng AL, Lin LI, Ho YS, Hsieh CY and Lin JK: Stability of curcumin in buffer solutions and characterization of its degradation products. J Pharm Biomed Anal 15: 1867-1876, 1997.

25. Tomren MA, Másson M, Loftsson T and Tønnesen HH: Studies on curcumin and curcuminoids XXXI. Symmetric and asymmetric curcuminoids: stability, activity and complexation with cyclodextrin. Int J Pharm 338: 27-34, 2007.

26. Grogan G: Emergent mechanistic diversity of enzyme-catalysed beta-diketone cleavage. Biochem J 388: 721-730, 2005.

27. Liang G, Shao L, Wang Y, Zhao C, Chu Y, Xiao J, Zhao Y, Li X and Yang S: Exploration and synthesis of curcumin analogues with improved structural stability both in vitro and in vivo as cytotoxic agents. Bioorg Med Chem 17: 2623-2631, 2009.

28. Somers-Edgar TJ, Taurin S, Larsen L, Chandramouli A, Nelson MA and Rosengren RJ: Mechanisms for the activity of heterocyclic cyclohexanone curcumin derivatives in estrogen receptor negative human breast cancer cell lines. Invest New Drugs 29: 87-97, 2011

29. Yadav B, Taurin S, Rosengren RJ, Schumacher M, Diederich M, Somers-Edgar TJ and Larsen L: Synthesis and cytotoxic potential of heterocyclic cyclohexanone analogues of curcumin. Bioorg Med Chem 18: 6701-6707, 2010.

30. Du ZY, Bao YD, Liu Z, Qiao W, Ma L, Huang ZS, Gu LQ and Chan AS: Curcumin analogs as potent aldose reductase inhibitors. Arch Pharm (Weinheim) 339: 123-128, 2006.

31. Zheng X, Cui XX, Avila GE, Huang MT, Liu Y, Patel J, Kong AN, Paulino R, Shih WJ, Lin Y, Rabson AB, Reddy BS and Conney AH: Atorvastatin and celecoxib inhibit prostate PC-3 tumors in immunodeficient mice. Clin Cancer Res 13: 5480-5487, 2007.

32. Ploszaj T, Motyl T, Orzechowski A, Zimowska W, Wareski P, Skierski J and Zwierzchowski L: Antiapoptotic action of prolactin is associated with up-regulation of Bcl-2 and down-regulation of Bax in $\mathrm{HC} 11$ mouse mammary epithelial cells. Apoptosis 3 : 295-304, 1998

33. Zheng X, Chang RL, Cui XX, Avila GE, Lee S, Lu YP, Lou YR, Shih WJ, Lin Y, Reuhl K, Newmark H, Rabson A and Conney AH: Inhibitory effect of 12-O-tetradecanoylphorbol-13-acetate alone or in combination with all-trans-retinoic acid on the growth of $\mathrm{LNCaP}$ prostate tumors in immunodeficient mice. Cancer Res 64: 1811-1820, 2004.

34. Romero-Weaver AL, Wang HW, Steen HC, Scarzello AJ, Hall VL, Sheikh F, Donnelly RP and Gamero AM: Resistance to IFN-alpha-induced apoptosis is linked to a loss of STAT2. Mol Cancer Res 8: 80-92, 2010.

35. Zheng X, Chang RL, Cui XX, Avila G, Huang MT, Liu Y, Kong AN, Rabson AB and Conney AH: Inhibition of NF- $\mathrm{AB}$ by (E)3-[(4-methylphenyl)-sulfonyl]-2-propenenitrile (BAY11-7082; $\mathrm{BAY}$ ) is associated with enhanced 12-O-tetradecanoylphorbol-13acetate-induced growth suppression and apoptosis in human prostate cancer PC-3 cells. Int J Oncol 32: 257-264, 2008.
36. Chen A and Zheng S: Curcumin inhibits connective tissue growth factor gene expression in activated hepatic stellate cells in vitro by blocking NF- $\mathrm{KB}$ and ERK signalling. Br J Pharmacol 153: $557-567,2008$

37. Li L, Aggarwal BB, Shishodia S, Abbruzzese J and Kurzrock R: Nuclear factor $-\kappa \mathrm{B}$ and $\mathrm{I} \kappa \mathrm{B}$ kinase are constitutively active in human pancreatic cells, and their down-regulation by curcumin (diferuloylmethane) is associated with the suppression of proliferation and the induction of apoptosis. Cancer 101: 2351-2362, 2004.

38. Aggarwal BB: Nuclear factor- $\kappa B$ : the enemy within. Cancer Cell 6: 203-208, 2004.

39. Arlt A, Gehrz A, Müerköster S, Vorndamm J, Kruse ML, Fölsch UR and Schäfer H: Role of NF-kappaB and Akt/PI3K in the resistance of pancreatic carcinoma cell lines against gemcitabine-induced cell death. Oncogene 22: 3243-3251, 2003.

40. Holley AK, Xu Y, St Clair DK and St Clair WH: RelB regulates manganese superoxide dismutase gene and resistance to ionizing radiation of prostate cancer cells. Ann NY Acad Sci 1201: 129-136, 2010.

41. Karin $\mathrm{M}$ : $\mathrm{NF}-\kappa \mathrm{B}$ as a critical link between inflammation and cancer. Cold Spring Harb Perspect Biol 1:a000141, 2009.

42. Royuela M, Rodríguez-Berriguete G, Fraile B and Paniagua R: TNF- $\alpha / \mathrm{IL}-1 / \mathrm{NF}-\kappa \mathrm{B}$ transduction pathway in human cancer prostate. Histol Histopathol 23: 1279-1290, 2008.

43. Paule B, Terry S, Kheuang L, Soyeux P, Vacherot F and de la Taille A: The NF- $\mathrm{KB} / \mathrm{IL}-6$ pathway in metastatic androgen-independent prostate cancer: new therapeutic approaches? World J Urol 25: 477-489, 2007.

44. Flynn V Jr, Ramanitharan A, Moparty K, Davis R, Sikka S, Agrawal $\mathrm{KC}$ and Abdel-Mageed AB: Adenovirus-mediated inhibition of NF- $\mathrm{KB}$ confers chemo-sensitization and apoptosis in prostate cancer cells. Int J Oncol 23: 317-323, 2003.

45. Wang D, Veena MS, Stevenson K, Tang C, Ho B, Suh JD, Duarte VM, Faull KF, Mehta K, Srivatsan ES and Wang MB: Liposome-encapsulated curcumin suppresses growth of head and neck squamous cell carcinoma in vitro and in xenografts through the inhibition of nuclear factor $\kappa \mathrm{B}$ by an AKT-independent pathway. Clin Cancer Res 14: 6228-6236, 2008.

46. Kasinski AL, Du Y, Thomas SL, Zhao J, Sun SY, Khuri FR, Wang CY, Shoji M, Sun A, Snyder JP, Liotta D and Fu H: Inhibition of IkappaB kinase-nuclear factor-kappaB signaling pathway by 3,5-bis(2-flurobenzylidene)piperidin-4-one (EF24), a novel monoketone analog of curcumin. Mol Pharmacol 74: 654-661, 2008 